diseased cornea; bilateral lymphoblastoma of the orbit with leucaemia showing cell inclusions ; two uncommon orbital tumours; and an interesting sequence of congenital glaucoma in four Hindu males. Illustrations of the more important cases are included.

\title{
OBITUARY
}

\section{ANDREW STANFORD MORTON}

THE death of Mr. Stanford Morton was noted in our last number. An elder son of the late John Morton, M.D., of the old H.E.I.C.S., he was educated at Edinburgh and University College, London. He qualified M.B.Edin., in 1874, and took the F.R.C.S.Eng., in 1888. His first ophthalmic appointment, so far as we are aware, was that of House Surgeon at Moorfields, where he had as a colleague the late Mr. Marcus Gunn. As Clinical Assistant at Moorfields he served for the extremely long period of sixteen years before he was elected to the staff. Before this he had held the post of Surgeon to the Royal Eye Hospital, Southwark, and at a later date, that of Ophthalmic Surgeon to the Great Northern Hospital, while rather late in life he accepted the post of Ophthalmic Surgeon to the Italian Hospital. He retired from practice in 1920, and went to live at Clifton, where he died on April 11 in his seventy-ninth year.

Morton's fame will last as long as the ophthalmoscope which bears his name endures; since its inception it has never been improved; in fact it is to be doubted whether it is capable of improvement; it has undoubtedly been the best on the market ever since, and we should be surprised to hear of any other being generally used at the present time:

There can be no question that Morton was, in his day, unsurpassed as an operator upon the eye. In particular, his results in cases of conical cornea, in which he had excised a small elliptical piece of the cone, were surprisingly good. For many years he conducted an operative surgery class, and many of those who were his students will remember the infinite trouble he took to improve their operative technique. His best-known work was a small handbook on Refraction of the Eye, which went through several editions; he was a first class draughtsman, as is exemplified by reproductions of several of his beautiful ophthalmoscopic drawings among the coloured plates of the Transactions of the Ophthalmological Society. He did not write much, nor did he take any great part in the meetings of the Ophthalmological Society, of 
which he had been an original member, and at one time VicePresident.

On completion of his time of service at Moorfields he was elected Consulting Surgeon to the Hospital; and he received the honour of Chevalier of the Crown of Italy for his services in connection with the Italian Hospital.

\section{NOTES}

WE learn with deep regret of the death on Deaths May 2 of Professor E. H. Starling, F.R.S., the well-known physiologist, while on a visit to the West Indies. Of Starling's great work as a physiologist this is not the place for a detailed account, but we may remind our readers that he published two papers in 1904 and 1906 on the intraocular pressure in collaboration with E. E. Henderson.

We have also to record with much regret the death of $\mathrm{Mr}$. WAREN Tay. We hope to publish an obituary notice in our next number.

\section{Presentation to Mr.} Treacher Collins

$\mathrm{Mr}$. Treacher Collins, on his retirement from the consulting staff of the White Oak School, Swanley, was presented by the staff and children of the school, with a silver cup as a token of appreciation of his services, extending over many years, to the Institution.

$\stackrel{*}{\mathrm{~W}_{\mathrm{F}} \text { are indebted to }}{ }^{*}{ }^{*}$ r. C. J. Henderson, of Cataract Sind, President, Blind Relief Association, for the information that the ordinary Indian word for a cataract is "Moti," which means pearl, but that cataract is also called "moti pāni" (pearl water). Glaucoma is "karo pāni" (black water) in Sindhi.

\section{FUTURE ARRANGEMENTS}

\section{7}

June 10.-Royal Society of Medicine, Section of Ophthalmology (Annual).

July 7-9.-Annual Meeting of the Oxford Ophthalmological Congress at Oxford.

July 20-22.-The British Medical Association, Section of Ophthalmology, at Edinburgh. 